\title{
Hanya Holm
}

March 3, 1893 - November 3, 1992

Hanya Holm, one of the century's major choreographers of modern dance and Broadway musicals, was highly regarded and sought after as an innovative master educator. Holm is credited with introducing improvisation, Labanotation, and theories of spatial dynamics to the American dance scene.

Born in Worms-am-Rhein, Germany, she was baptized Johnna Eckert. Trained at both the Hoch Conservatory of Music and the Dalcroze Institute, she joined Mary Wigman in 1921 and became part of the development of "German Expressionist Dance." For ten years she toured Europe as a principal dancer with Wigman's company and became chief instructor at the Central Institute in Dresden. During that time she changed her name to Hanya Holm.

When impresario Sol Hurok offered to finance a Wigman school in America, Hanya, nervous about the political undercurrents of Hitler's rise, volunteered to relocate. Hurok arranged everything: her travel, the studio, her housing. The day after arriving, Hanya began teaching (September 25, 1931). Hurok, a businessman and producer, was not interested in waiting the five years Hanya needed to train a company. So, in 1932 he turned the school over to her. (As promised, she did have a trained company by 1936 !)

During summers Hanya taught at Mills College, California in 1932 and Perry Mansfield, Colorado in 1933. Finding that Wigman's mysticism and Germanic themes had little to do with American temperament, environment, or rhythms, she developed her own theories and created a modern style which encouraged freedom and a flowing quality for the torso and back, and yet was firmly based on universal principles of motion and the laws of physics. Her natural sense of humor blossomed, and while her choreography was still concerned with visionary messages about humanity's relation to the universe, the dancing was lyrical, witty, and open. Invited to teach at the famous Bennington Summer School of the Dance from 1934 to 1941, she was recognized as one of the "four pioneers" of American modern dance. In 1941 she founded the influential summer program at Colorado College, Colorado Springs, where she taught for fortythree years.

Her New York school and the summer program became meccas for dancers of all disciplines. Critic Walter Terry commented that any dancer, whether East Indian, tap, ballet, or any other style, could become a better dancer because Hanya's theories could be applied to all. Her three-year program offered technique, anatomy, theory, dance history, pedagogy, composition, improvisation, and Labanotation. Famous students include Alwin Nikolais, Valerie Bettis, Glen Tetley, Mary Anthony, Louise Kloepper, Nancy Hauser, Don Redlich, Anabelle Lyon, Bambi Lynn, and Murray Louis.

Holm's masterwork, Trend, commissioned by the Bennington Festival in 1937, had as its central theme the survival of society. Stunning for its architectural form, symphonic development, and emotional intensity, Trend received the New York Times Award for Best Dance. In 1939 Dance Magazine awarded Holm's Tragic Exodus Best Group Choreography. Also in 1939, Metropolitan Daily was selected by the National Broadcasting Company (NBC) for the first live telecast of modern dance. Viewers within a fifty-mile radius of New York city were treated to Holm's witty and satiric views of newspapers.

Hanya gained distinction as a choreographer/director for opera, theatre, and Broadway. After her success with Ballet Ballads (1948) she was invited to choreograph a new Cole Porter musical. Kiss Me Kate (1948) was unanimously greeted as a milestone in the development of the American musical and Holm was recognized with a New York Drama Critics Award as Best Choreographer that year. At Hanya's request, the Labanotation score was registered with the Library of Congress in 1952, the first complete choreography to be so copyrighted.

Hanya choreographed for musicals throughout the $1950 \mathrm{~s}$ and 1960s, earning special accolades for The Golden Apple (1954) and great acclaim for My Fair Lady (1956). For her work on this smash hit, she was nominated for a Tony Award. In his New York Times review John Martin summed up her influence:

Hanya Holm should get some sort of specially designed gold medal for what she has done with $M y$ Fair Lady . . . . It is just about as ideal a fusion of the literary-dramatic element of the theatre with the choreo-musical element as has been seen in our time.

Other Broadway musicals included My Darlin' Aida (1952), Camelot (1960), and Anya (1965), and among her film/ television creations were The Vagabond King (Paramount, 1956), The Dance and the Drama (Canadian Broadcasting Company, 1957), and Dinner with the President (CBS 1963).

During the 1970s and 1980s the Don Redlich Dance Company became the chief repository for Hanya's concert dances. For its 1985 New York season the company presented Ratatat (1982), Jocose (1983), and Capers (1985). These dances revealed that the Holm wry sense of humor, wit, poignancy, and keen intelligence were as sharp and vital as during the pioneering decade.

Among her numerous prestigious awards were DanceMagazine, Capezio, Samuel H. Scripps/American Dance Festival, Fred Astaire, and the Theater Hall of Fame. She remained essentially unimpressed with her greatness as an artist and ever committed to generously sharing all she knew. Her teaching at Juilliard, the Nikolais-Louis studio, and Colorado College extended until she was well past age 90. As an Honored Guest at the American Film Institute, Kennedy Center, Washington, D.C. for the 1985 Women in Film and Video Festival, she repeated one of her famous remarks, "You will find out that one life is not enough. You will want to have several lives in which to discover what there is to be discovered."

Marilyn Cristofori University of Hawaii at Manoa 